\title{
APLIKASI SOFTWARE ACL SEBAGAI ALAT UNTUK MENDETEKSI PENYIMPANGAN KEUANGAN DAN AKUNTANSI PADA PT KAPUR PUTIH LAMPUNG
}

\section{Linda Santioso $^{1}$, Susanto Salim ${ }^{2}$, Andreas Bambang Daryatno ${ }^{3}$, dan Nurainun Bangun ${ }^{4}$}

\author{
${ }^{1}$ Jurusan Ekonomi Akuntansi, Universitas Tarumanagara \\ Email: lindas@fe.untar.ac.id \\ ${ }^{2}$ Jurusan Ekonomi Akuntansil, Universitas Tarumanagara \\ Email: susantos@fe.untar.ac.id \\ ${ }^{3}$ Jurusan Ekonomi Akuntansi, Universitas Tarumanagara \\ Email: andreasb@fe.untar.ac.id \\ ${ }^{4}$ Jurusan Ekonomi Akuntansi, Universitas Tarumanagara \\ Email: nurainunb@fe.untar.ac.id
}

\begin{abstract}
The business risk that often occurs and is very worried by the company is fraud or fraud. Fraud often occurs in small companies, although it is also possible for large companies to occur. Large companies in general already have antifraoud, funds are available and employees have carried out their supervisory functions optimally. ACL is an ACL (Audit Command Language) Software Application that can be used to help detect financial and accounting irregularities. The vulnerability of assets to be embezzled and weak controls require the company's internal audit to always carry out early detection to anticipate the possibility of existing frauds. Through the use of ACL, it is possible to analyze data and generate a report for inspection. ACLs can be operated even though the data is large, can read various data types, export results into various data types and are able to provide high-quality reports. The method used is to provide counseling, training and operation of the use of ACL in improving the supervision of the company's financial activities. With this counseling and training, it is hoped that all parts of the organization can be controlled and their activities controlled. Sales, purchasing, warehouse and production involved in company activities, can provide more transparent information to management, this can directly or indirectly improve performance and competitiveness for the company. The results obtained by using the ACL process can be done more efficiently. fast, accurate, precise, inexpensive, and time efficient, saving energy and costs for the company.
\end{abstract}

Keywords: Audit Command Language, detecting, Financial and accounting control, Company activities.

\begin{abstract}
ABSTRAK
Resiko bisnis yang sering terjadi dan sangat dikuatirkan oleh perusahaan adalah fraud atau kecurangan. Kecurangan seringkali terjadi pada perusahaan kecil walaupun tidak menutup kemungkinan terjadi pula di perusahaan besar. perusahaan besar pada umumnya sudah memiliki anti-fraoud, tersedia dana dan karyawan sudah menjalankan fungsi pengawasan secara optimal. ACL adalah Aplikasi Software ACL (Audit Command Language) yang dapat dipakai untuk membantu mendeteksi Penyimpangan keuangan dan akuntansi. Kerawanan aset untuk digelapkan dan kontrol yang lemah mengharuskan audit internal perusahaan senantiasa melakukan deteksi lebih awal untuk mengantisipasi kemungkinan terjadi kecurangan-kecurangan yang ada. Melalui penggunaan ACL dimungkinkan untuk dilakukan Analisa data dan menghasilkan suatu laporan untuk dilakukan pemeriksaan. ACL dapat dioperasikan walaupun datanya besar, bisa membaca berbagai tipe data, melakukan export hasil ke dalam berbagai tipe data dan mampu memberikan laporan berkualitas tinggi. Metode yang dipakai dengan memberikan penyuluhan, pelatihan dan pengoperasian penggunaan ACL dalam meningkatan pengawasan aktivitas keuangan perusahaan. Dengan adanya penyuluhan dan pelatihan ini diharapkan seluruh bagian dalam organisasi dapat terkontrol dan terkendali aktifitasnya. Penjualan, pembelian, Gudang dan produksi yang terlibat didalam aktifitas perusahaan, dapat memberikan informasi yang lebih transparan kepada manajemen, hal ini secara langsung maupun tidak langsung dapat meningkatkan kinerja dan daya saing bagi perusahaan.Hasil yang didapat dengan penggunaan ACL proses itu dapat dilakukan dengan lebih cepat, akurat, tepat, murah, dan efesiensi waktu, menghemat tenaga maupun biaya bagi perusahaan.
\end{abstract}

Kata Kunci: Audit Command Language, mendeteksi, Pengendalian keuangan dan akuntansi, aktifitas Perusahaan.

\section{PENDAHULUAN}

Analisis Situasi

Dalam menjalankan aktivitas perusahaan, biasa disusun suatu prosedur atau urutan kerja yang harus dilakukan supaya aktivitas perusahaan dapat dengan mudah dikendalikan. Prosedur atau 
urutan kerja yang biasa disebut dengan system informasi akuntansi yang didalamnya terdapat internal kontrol baik di dalam satu divisi maupun antar divisi yang ada di perusahaan. Menurut COSO, internal control didifinisikan sebagai suatu proses yang dibuat untuk mengendalikan perusahaan dalam mencapai tujuan dengan meningkatkan efisien dan efektif di bagian produksi, menghasilkan laporan keuangan yang mampu untuk dipertanggungjawabkan dan sesuai dengan peraturan dan undang-undang yang berlaku baik yang dilakukan oleh manajemen maupung karyawan (Hall, 2019).

Pengendalian internal yang disusun oleh perusahaan dalam prakteknya masih sulit mendeteksi adanya kecurangan atau fraud yang terdapat dalam perusahaan. Secara umum, para pengusaha tidak secara khusus untuk menghilangkan kemungkinan adanya kecurangan karena percaya akan kemampuan dari sistem pengendalian internal dalam perusahaan. Jika terjadi kecurangan, maka aset perusahaan dapat hilang tanpa menghasilkan keuntungan yang diharapkan. Para pengusaha tidak ada salahnya memahami juga pelaku-pelaku fraud atau kecurangan (Albrecht, 2004; "Kenali Kecurangan, n.d.)

Kecurangan atau fraud terdapat tiga jenis, yaitu: Corruption, Fraudulent Statements, Asset Misappropriation (ACFE, 2014). Teori Segitiga Kecurangan yaitu faktor penekan (pressure). kesempatan (opportunity) dan faktor rasionalisasi (rationalization) dalam Tjahjono, et al (2013); Ruankaew, T (2016) menyatakan seseorang yang pada awalnya bisa dipercaya bisa berubah Ketika menghadapi tekanan keuangan yang serius dimana masalah yang dihadapi tidak dibagikan kepada rekan kerja lainnya.Orang yang melakukan kecurangan akan mencari pembenaran secara rasional untuk membenarkan perbuatannya Cressey, (1953); Kurniawati, (2012). Berlandaskan definisi di atas, dapat disimpulkan bahwa kecurangan terdapat empat aktifitas yang harus dipenuhi, yaitu: Tindakan dilakukan secara sengaja oleh pelaku, Terdapat korban, Korban menuruti kemauan pelaku, Korban mengalami kerugian.

Pihak manajemen perusahaan mengundang kami para dosen Universitas Tarumanagara untuk mengadakan pertemuan dan melakukan diskusi atas masalah yang terjadi di unit usaha PT Kapur Putih Lampung berlokasi, di Ruko L'AGRICOLA Blok C/20 Gading Serpong Curug Sangereng Kelapa Dua Tangerang. Dari pertemuan kami dengan pihak manajemen, maka dapat kami ketahui keadaan dari unit usaha PT Kapur Putih Lampung bahwa:

1. Terjadi selisih persediaan bahan baku antara fisik dengan catatan dan

2. Pembelian dengan hutang dagang.

3. Terjadi selisih antara persediaan barang jadi dengan penjualan dan piutang dagang

Berdasarkan masalah yang dihadapi oleh perusahaan maka kami Tim Dosen Universitas Tarumanagara mengusulkan penggunaan Aplikasi Software ACL Sebagai Alat Untuk Mendeteksi Penyimpangan Keuangan dan Akuntansi.

\section{Permasalahan dan Solusi Mitra}

Berdasarkan analisis situasi saat bertemu dengan pimpinan perusahaan dan staf yang terkait, maka permasalahan mitra yang muncul dengan selisih persediaan bahan baku antara fisik dengan kartu stock dan pembelian dengan hutang dagang, Terjadi selisih antara persediaan barang jadi dengan penjualan dan piutang dagang. Maka untuk membantu menyelesaikan masalah yang dihadapi pihak manajemen PT Kapur Putih Lampung, kami tim dosen mengambil kesimpulan dimana perusahaan memerlukan alat bantu yang dapat dipakai untuk mendeteksi kemungkinan terjadinya kecurangan-kecurangan yang timbul. Dengan mengoperasikan dan memanfaatkan penggunaan ACL diharapkan: 
1. Mampu melakukan analisa data dan menghasilkan deteksi lebih awal jika terjadi kecurangan.

2. Mampu mengolah data dalam ukuran file besar.

3. Mampu membaca bermacam-macam jenis data.

4. Mampu menghasilkan bermacam-macam jenis data dan menampilkan laporan berkualitas tinggi.

Target dari aktivitas penyuluhan, dan pendampingan bagi perusahaan adalah perusahaan mendapatkan alat pengendalian dengan mendeteksi terjadinya penyimpangan keuangan dan akuntansi yang dapat dijadikan model kerja bagi perusahaan-perusahaan manufaktur lainnya terutama perusahaan yang menggunakan Aplikasi Software ACL (Audit Command Language).

Target dari aktivitas penyuluhan bagi Fakultas Ekonomi adalah dapat dijadikan bahan ajar atau modul bagi mata kuliah " Auditing " khususnya Teknik dalam mendeteksi terjadikan kecurangan (fraud) keuangan dan akuntansi bagi mahasiswa jurusan Akuntansi.

Target dari aktivitas penyuluhan bagi mahasiswa, diharapkan dapat menjelaskan bagaimana pengendalian, pendeteksian kecurangan dengan mengunakan aplikasi software ACL. Mampu membedakan pendeteksian antara sistem manual dengan sistem berbasis komputerisasi (Teknologi).

Dengan adanya penyuluhan, pelatihan dan pendampingan ini memunculkan kerjasama antara dunia pendidikan dan dunia usaha sehingga kedua belah pihak menghasilkan manfaat untuk kemajuan bersama.

\section{METODE PELAKSANAAN PKM}

Metode pelaksanaan kegiatan dilakukan melalui penyuluhan, pembinaan dan pelatihan untuk menggunakan ACL (Aplikasi Software ACL Sebagai Alat Untuk Mendeteksi Penyimpangan Keuangan dan Akuntansi). Pelaksanaan penyuluhan dan pelatihan dilakukan dengan 2 metode yaitu melalui daring dan kunjungan ke unit kerja di Gading serpong Tangerang. Saat kunjungan kami untuk memberikan pelatihan penggunaan ACL, manajemen dan staff dengan semangat yang tinggi merespon dengan baik untuk mempelajarinya. Mereka sangat berharap dengan kemudahan pengoperasian dan hasil deteksi dini jika terjadi penyimpangan atau kecurangan. Selama ini, jika terjadi masalah seperti selisih, ketidakcocokan stock maupun keuangan maka secara manual mereka harus menelusuri dokumen ke dokumen lainnya untuk menemukan ketidaksesuaian yang terjadi. Prof. Hart J. Will dari Canada mengembangkan ACL pada tahun 1970-an dan kemudian dikelola oleh $A C L$ Services Ltd, Vancouver, Canada. Pada tahun 2005, ACL adalah pemimpin pasar dalam penggunaan, pengambilan, analisa data serta pelaporan dalam penggunaan teknologi. $A C L$ terus berkembang dengan meningkatkan fungsi dalam memenuhi kebutuhan analisis data dalam operasional perusahaan. Dibidang audit $A C L$ digunakan dalam analisis, pencocokan, pembandingan data dan pelaporan penyimpangan.

Adapun kemampuan ACL adalah sebagai berikut:

a. Dapat digunakan dengan mudah.

ACL for Windows, sangat mudah digunakan (User Friendly) yang semua orang memakainya dalam kehidupan sehari-hari. User tinggal mengklik icon dalam melakukan suatu pekerjaan, dan ada dukungan fasilitas Wizard untuk mendefinisikan data yang akan dianalisis.

b. Built-in audit dan analisis data secara fungsional. 
ACL for Windows mempunyai kemampuan melakukan Analisa pemeriksaan atau audit seperti : Analisis Statistik, Menghitung total, stratifikasi, sortir, index.

c. Mampu mengolah file yang ukurannya relatif besar

ACL for Windows sanggup mengolah bermacam-macam jenis file dengan ukuran file yang ukurannya besar.

d. Kemampuan untuk membaca berbagai macam tipe data.

ACL for Windows sanggup mengolah file dari format lain seperti : Flat sequential, dBase (DBF), Text (TXT), Delimited, Print, ODBC (Microsoft Access database,Oracle), Tape ( $1 / 2$ inch 9 - track tapes, IBM 3480 cartridges, $8 \mathrm{~mm}$ tape dan 4 mm DAT.).

e. Hasil pemeriksaan dapat ditransfer dalam bentuk format data seperti: Plain Text (TXT), dBase III(DBF), Delimit(DEL), Excel (XLS), Lotus (WKS), Word (DOC) dan WordPerfect (WP).

\section{HASIL DAN PEMBAHASAN}

\section{Hasil dan Pembahasan}

Berdasarkan permasalahan mitra yang muncul dimana terdapat selisih persediaan bahan baku antara fisik dengan kartu stock, pembelian dengan hutang dagang dan selisih antara persediaan barang jadi dengan penjualan dan piutang dagang. Setelah mendapatkan pelatihan yang diberikan oleh Dosen Universitas Tarumanagara maka dilakukan uji coba penggunaan aplikasi software ACL dengan hasil sebagai berikut:

1) Selisih persediaan bahan baku antara fisik dengan kartu stock, diketahui masalah dimana selisih tersebut disebabkan antara lain: terdapat beberapa pengeluaran dan pemasukan yang tidak tercatat dalam kartu stock padahal secara fisik terjadi transaksi tersebut, adanya retur bahan karena tidak lolos QC dan pencatatan bahan baku masuk tidak berdasarkan fisik yang diterima, tetapi berdasarkan surat jalan dari pemasok.

2) Selisih pembelian dengan hutang dagang disebabkan saat dilakukan pembelian bahan sebanyak 100 pcs, sebagian tidak lolos QC sebanyak 5 pcs dengan janji pemasok akan melakukan penggantian bahan tersebut. Tetapi sampai dilakukan uji coba pemakaian aplikasi software ACL bahan tersebut belum diganti, saat penagihan ke bagian hutang dagang dimana pemasok tetap menagihkan sesuai dengan surat jalan saat barang diterima oleh bagian penerimaan.

3) Selisih antara persediaan barang jadi dengan penjualan dan piutang dagang, terjadi saat pelanggan melakukan perubahan order pembelian, bagian penjualan sudah melakukan perbaikan order tetapi dokumen perubahan tidak terdistribusi ke bagian gudang barang jadi sehingga antara fisik barang yang dikeluarkan, dokumen penjualan dan piutang dagang timbul selisih karena perbedaan harga antara item barang jadi awal dengan item barang jadi perubahan. Selain itu ditemukan adanya uang masuk dari rekening koran yang seharusnya untuk melunasi piutang dagang, tetapi oleh bagian akuntansi di masukkan ke uang muka penjualan karena tidak jelas pelanggan dan nomor invoice mana yang harus dilunasi.

Implementasi penyuluhan dan pelatihan dimana sebagian dilakukan via zoom (online) dan kunjungan perusahaan saat uji coba penggunaan aplikasi ACL dapat dilihat pada Gambar 1.

\section{b. Luaran yang Dicapai}

Dengan penggunaan aplikasi software ACL maka perusahaan mempunyai alat pendeteksian bagian keuangan dan akuntansi. Setelah dilakukan uji coba maka memberikan pengendalian terhadap transaksi-transaksi yang selama ini perusahaan mengalami kesulitan untuk mencari 
penyebab timbulnya selisih. Hal ini tentunya memberikan pengendalian terpadu di internal perusahaan.

Dari hasil pengoperasian aplikasi software ACL maka hasil luaran yang dirasakan manfaatnya bagi perusahaan adalah sebagai berikut:

1. Melalui penggunaan ACL diharapkan dapat untuk menganalisa data dan menghasilkan laporan audit untuk user non teknis, Mampu menangani ukuran file yang tak terbatas, Mampu membaca berbagai macam tipe data, Mampu mengekspor hasil ke berbagai macam tipe data dan menampilkan laporan berkualitas tinggi.

2. Memberikan penelusuran yang jelas terhadap transaksi-transaksi yang terjadi di perusahaan secara lebih jelas, sehingga terhindar kerancuan terhadap apa yang selama ini tidak diketahui penyebab terjadinya selisih.

3. Memudahkan komunikasi transaksi di internal divisi maupun antar divisi sehingga menimbulkan pola kerja yang lebih transparan, dimengerti oleh bagian-bagian yang terkait, ditaati dan dijalankan sehari-harinya.

4. Mempercepat penyelesaian masalah-masalah yang selama ini muncul di perusahaan, sehingga tercipta pola kerja yang lebih efisien dan efektif, mengurangi ketidakpastian, dan meningkatkan kinerja perusahaan.

5. Mengkomunikasikan antar bagian jika timbul masalah sehingga dapat diketahui secara pasti penyebab, cara memperbaiki masalah supaya tidak terulang kembali terhadap transaksi berikutnya.

6. Memberikan alat ukur dan pengendali kinerja divisi dan antar divisi, dan menyediakan informasi yang mendasari perlu-tidaknya dilakukan tindakan koreksi.

\section{Gambar 1}

Implementasi Penyuluhan dan Pelatihan

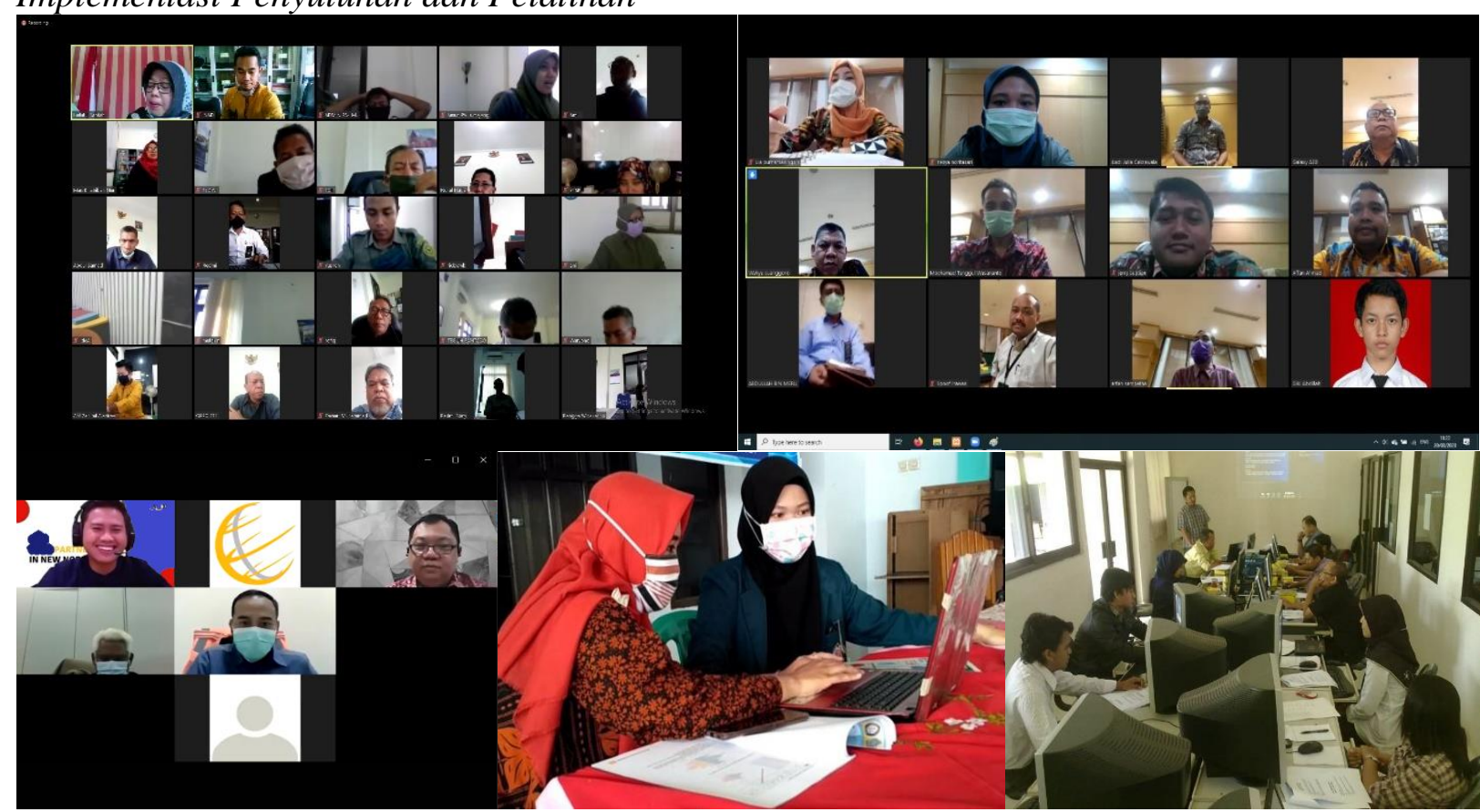




\section{KESIMPULAN DAN SARAN}

Pada umumnya proses auditing memakan waktu lama dikarenakan tingkat kompleksitasnya. Dengan $A C L$ proses itu dapat dilakukan dengan lebih cepat, akurat, tepat, murah, dan dengan lingkup analisa lebih luas dan mendalam. Selain keuntungan dari segi efesiensi waktu, ACL juga menghemat tenaga maupun biaya bagi perusahaan. Keuntungan lain yang didapatkan yaitu indikasi penyimpangan finansiial dapat ditemukan lebih mudah, cepat, dan akurat sehingga dapat segera diupayakan tindak lanjut dari segi hukum. Dengan alat bantu ACL software yang diterapkan maka dapat diketahui adanya a) Selisih persediaan bahan baku antara fisik dengan kartu stock, b) Selisih pembelian dengan hutang dagang, c) Selisih antara persediaan barang jadi dengan penjualan dan piutang dagang.

\section{REFERENSI}

Albrecht, W.S. (2004). Fraud examination \& prevention. Thompson Learning.

Ashari, (2018). Teknik audit berbantuan komputer dengan ACL. ElecKomputindo.

Association of Certified Fraud Examiner (ACFE). (2014). Report to the nations on occupational fraud and abuse.

Cressey, D. (1953). Other people's money: A study in the social psychology of embezzlement. Glencoe. IL. Free Press.

Hall, J.A. (2019). Accounting information system. 10th. Cengage.

Kurniawati, E. (2012). Analisa faktor-faktor yang mempengaruhi financial statement fraud dalam perspektif froud triangle.

Moeller, R. R. (2014). Executive's guide to COSO internal controls: understanding \& implementing the new framework. John Wiley \& Sons.

Ruankaew, T. (2016). Beyond the fraud diamond. International Journal of Business Management and Economic Research (IJBMER), 7(1). 474- 476.

Tjahjono, S. et al. (2013). Business crimes and ethics.

Kenali kecurangan finansial dalam perusahaan anda! (n.d.) https://www.jurnal.id/id/blog/kenalipelaku-fraud-dalam-perusahaan-anda/ 